\title{
Moving society to a sustainable future: The framing of sustainability in a constructive media outlet
}

\author{
Dimitrinka Atanasova, Lancaster University
}

\begin{abstract}
News reporting on sustainability has been criticized for (1) having a limited coverage of solutions, (2) reporting on solutions with a negative bias, (3) being dominated by sources from government and mainstream business, and (4) promoting frames that prioritize the role of the market and techno-scientific solutions, which leave unchallenged the unsustainable behavior of consumer societies and the focus on economic growth. This study was the first to examine how sustainability is reported in a constructive media outlet and found that articles (1) consistently elaborated solutions, (2) described them in optimistic ways, (3) quoted various sources, and (4) developed a frame that challenged consumerism and critiqued society's preoccupation with growth while helping to imagine a desirable sustainable future. It is thus argued that this novel, constructive approach to journalism can help move society to a sustainable future by expanding the repertoire of culturally-resonant stories to live by.
\end{abstract}

\section{Keywords}

sustainability, constructive journalism, framing, qualitative analysis, UK

\section{Introduction}

Sustainability can be broadly understood in terms of "futurity" or the ability of present generations to meet their needs without compromising future generations' ability to do so (Basiago, 1995, p. 109). This definition of sustainability emerged over 30 years ago, when the concept was first used by the World Commission on Environment and Development (WCED) (WCED, 1987). A more specific and recent definition suggests that sustainability relates to achieving a balance between social justice (people), economic progress (profit) and ecological interests (planet) (Elkington, 1997). The news media are among the most important channels through which the general public comes to understand what sustainability is about and how it can be achieved (Ziemann, 2011). At the same time, the news representation of sustainability has received considerably less research attention compared to the related topics of climate change and environmental degradation (see e.g. Bonfadelli, 2009; Diprose et al., 2017; Yacoumis, 2017).

\section{Sustainability coverage}

Studies which have examined sustainability-related news coverage identify several tendencies. (1) News articles rarely offer information on solutions to sustainability problems (Bonfadelli, 2009) - an inclination that characterizes environmental reporting as a whole (e.g. Kensicki, 2004; Major \& Atwood, 2004). (2) Where solutions are mentioned, they tend to be reported "with a negative bias" (Bonfadelli, 2009, p. 275) by presenting the most optimal ones as ultimately impossible to implement due to their high economic costs. (3) News articles tend to rely on a narrow range of sources from government and mainstream business (Bonfadelli, 2009; Diprose et al., 2017; Lewis, 2000; Yacoumis, 2017), which is not dissimilar to reporting on climate change and the environment (Anderson, 2017; Hansen, 2010) as well as general news reporting trends (Hall et al., 1978). The reliance on sources from government and mainstream business in sustainability reporting has prompted critiques that the media reinforce the preferred meanings or sustainability frames of powerful groups and institutions (Donohue, Tichenor, \& Olien, 1995). (4) The frames that have been found to dominate sustainability reporting, indeed, appear to (i) position businesses as central to realizing sustainability 
solutions (powered by consumer demand for sustainably produced goods and services), and/or (ii) advance the idea that the solutions to sustainability issues are largely scientific and technological in nature and human creativity coupled with technological progress holds the key to a sustainable future.

Such frames have been variously labelled. In a study of Australian print newspapers, Yacoumis (2017) described the frames ${ }^{i}$ win-win: the language of business ${ }^{i i}$ and human ingenuity and the promise of technology. The former argued that increased consumer awareness of sustainability is creating opportunities for businesses and simultaneously persuaded consumers that by opting for green products they can enhance their lifestyles, reduce their costs, and lower their environmental impacts. The latter promoted the idea that better environmental outcomes can be achieved through more efficient, smarter technologies. Analyzing British print newspapers, Diprose et al. (2017) identified an economic frame which invoked the responsibility of businesses to work sustainably and of consumers to choose green products and it also demonstrated faith in scientific innovations. In a study of print newspapers published in the United States (US), Lewis (2000) described an economic growth frame, which presented economic development and technology as the most effective ways to achieve sustainability. The common focus across these studies on the role of business, consumer choices, and the techno-scientific management of nature has also been observed in the wider reporting on climate change and the environment. Hellsten, Porter, and Nerlich (2014, p. 479) identify a focus on "big business (...) and the lifestyles of private consumers" in such coverage, while Koteyko (2012) finds considerable overlap between climate change, business, and lifestyle lexis (demonstrated in expressions such as "carbon accounting" and "low-carbon diet").

The above frames of sustainability have been criticized for promoting a "green growth"/“ecological modernization" paradigm (e.g. Bäckstrand \& Lövbrand, 2006; Prádanos, 2018). An approach prominently espoused by the United Nations (UN) (UN, 2015), it posits that economic growth, social justice, and ecological protection are fully compatible. Critics have however argued that: this approach fails to recognize that consumer culture bears responsibility for the changes of the planet's ecological systems (Prádanos, 2018); continued economic growth which comes with ever-increasing resource consumption is incompatible with maintaining the ecological foundations of our societies (Ehrich \& Ehrich, 2013), and the "green growth"/“"ecological modernization" paradigm sets up "expectations that are not always possible if the goal is indeed a serious attempt to reduce the industrial propensity to damage the earth" (Prasad \& Elmes, 2005, p. 857). The extent to which technological progress can offset the ecological impacts of continued resource consumption has been questioned (Kemp \& van Lente, 2011) as has been the uncritical view within the "green growth"/"ecological modernization" paradigm of the unsustainable behavior of consumer societies (Bäckstrand \& Lövbrand, 2006). The above-described frames can, in these terms, be said to condone "green consumerism" where the buying of sustainably produced goods that is encouraged serves little purpose beyond easing people's guilt (Princen, Maniates, \& Conca, 2002).

These characteristics of sustainability reporting have been attributed to the economic model and editorial priorities of mainstream news outlets (Bonfadelli, 2009). Their dependence on corporate advertising (Herman \& Chomsky, 1988) limits the options for challenging the status quo of consumerism and the range of solutions that can be reported. Research into news values - internalized journalistic rules acquired during professional socialization which guide the selection of newsworthy issues ${ }^{\mathrm{iii}}$ - has shown that mainstream news is generally defined by "negativity" and "surprise" (e.g. Bell, 1991; Galtung \& Ruge, 1965; Harcup \& O'Neill, 2017), and "negativity" in particular has been termed "the basic news value" (Bell, 1991, p. 156). Applied to sustainability, preference for these news values dictates that, as a long-term issue, it would rarely enter the news and when it does it would be covered in negative terms 
(Bonfadelli, 2009). The value that mainstream news outlets place on "objectivity" and the way in which it has traditionally been operationalized might help explain the reliance on sources from dominant institutions in society. Faced with busy schedules and litigation risks, journalists need clear guidelines allowing them to claim a news article has been approached objectively (Boudana, 2011; Tuchman, 1972). These procedures include separating facts from opinions, balancing "truth-claims" by giving voice to both or all sides involved in a story, and importantly, drawing on conventionally "authoritative" sources (Tuchman, 1972, p. 665).

\section{Constructive journalism}

The media landscape has however been changing and media outlets which practice constructive journalism and have a different economic model, news values focus, and take on objectivity have been proliferating. While there is no agreed definition of constructive journalism and terms are used inconsistently ${ }^{\text {iv }}$, it can be understood as "an emerging form of journalism that involves applying positive psychology techniques to news processes (...) to create productive and engaging coverage, while holding true to journalism's core functions" (McIntyre \& Gyldensted, 2017, p. 20). It envisions a "more active" role of the journalist (McIntyre \& Gyldensted, 2017, p. 22) in the sense of showing concern about the possible effect of the news on society's wellbeing. Constructive journalism also has a more "active" orientation in terms of its ambition to give people an opportunity to act by covering stories about how social problems are being responded to (Gyldensted, 2015; Haagerup, 2017).

The principles of constructive journalism have been espoused by mainstream and dedicated publications. Some mainstream media outlets have introduced special sections that adopt a constructive approach (e.g. the BBC's "World Hacks", the New York Times" "Fixes" and "The Week in Good News", The Washington Post's "The Optimist"). Others have incorporated constructive journalism into their regular coverage, training journalists to adopt a constructive approach throughout their work (e.g. The Montgomery Advertiser). The first publication dedicated to constructive journalism was Positive News in the United Kingdom (UK), which is being joined by a growing list of media outlets worldwide from Germany (e.g. Perspective Daily) to South Africa (e.g. South Africa: The Good News) (Green, 2018). This type of dedicated media outlets is funded primarily through membership fees and crowdfunding campaigns.

Ultimately, constructive journalism seeks to redefine the dominant negative news angle and challenge the newsroom slogan that "if it bleeds, it leads" (Gyldensted, 2015; Haagerup, 2017). It should not however be confused with "positive news" referring to entertaining and emotional news articles on topics of limited societal significance (Gyldensted, 2015; McIntyre $\&$ Gyldensted, 2017). Constructive journalism reports on important issues by "add[ing] a solution-oriented framing" (McIntyre \& Gyldensted, 2018, p. 666) and covering "people doing something extraordinary to solve important problems" (Haagerup, 2017, p. 17). In addition to the five "W-s" of mainstream journalism ("what", "where", "when", "who" and "why"), it asks "what now" (Gyldensted, 2015; Haagerup, 2017). In sum, a constructive news article is not about ignoring negative news - it contains the problem definition, but "takes us a step further because it shows a possible solution" (Haagerup, 2017, p. 93).

Nor is constructive journalism to be conflated with advocacy, as it adheres "to the same objectivity concerns journalism is facing" (Lough \& McIntyre, 2018, p. 1). At the same time, it can be argued that it has a different take on objectivity and particularly on balance. Instead of stressing the balancing of both or all sides, it stresses the need to balance stories of conflict and setback with those about cooperation and progress (McIntyre \& Gyldensted, 2017, 2018). The balancing of "truth-claims" as an objectivity strategy (Tuchman, 1972, p. 665) where climate scientists and skeptics have been given equal access to the news has been implicated in the misrepresentation of climate science as unsettled, which has, in turn, been linked to 
inaction on climate change (Boykoff, 2007). In contrast, constructive journalism's emphasis on balancing the reporting of problems with that of solutions might help empower action (Curry \& Hammonds, 2014) $)^{\mathrm{v}}$.

\section{Framing}

Solutions or "treatment recommendations" are, in fact, one of the four functional features of a frame as per Entman's (1993, p. 52) popular in journalism and media and communication studies definition of frames and framing (see Matthes, 2009). Within this definition, framing refers to selecting aspects of a perceived reality and making them "more salient in a communicating text, in such a way as to promote a particular problem definition, causal interpretation, moral evaluation, and/or treatment recommendation" (Entman, 1993, p. 52). While framing is an active and strategic process, frames are the more static interpretative packages that get embedded in news articles at the news production stage and can be subsequently reconstructed by researchers through text analysis (Entman, 1993).

There has been much debate whether frames reside in the minds of journalists or audience members (see Scheufele, 1999). Conceptualizing them as "media" versus "audience" frames may however create the confusion that frames are everywhere and yet nowhere (van Gorp, 2007, 2010). This paper adopts the view that frames can be more usefully seen as located in culture. Journalists and audience members draw on a shared "cultural reservoir" (van Gorp \& van der Goot, 2012, p. 130) of beliefs, myths, norms and values to attribute meaning to issues (see also Entman, 1993; Gamson \& Modigliani, 1992). In this sense, frames work much like conceptual metaphors where knowledge from one domain is applied to talk (and potentially think) about another domain (Lakoff \& Johnson, 1980). For example, the norm shared by Western societies that a person should exercise self-control over one's body has been invoked to frame various issues (e.g. Lakoff, 1995).

The centrality of culture to frames and framing has been recognized in the earliest, foundational literature (e.g. Entman, 1993; Gamson \& Modigliani, 1992). Entman (1993, p. 53) describes culture as "a stock of commonly invoked frames (...) exhibited in the discourse and thinking of most people in a social grouping", which allows frames to have a common effect on most people sharing a culture. The importance of culture has been further highlighted more recently through van Gorp's (2007) term "culturally-embedded" frames and his systematic (qualitative, inductive) procedure for frame analysis which links Entman's (1993) four functional features of a frame (problem definition, causes, moral evaluations, solutions) to a culturally-shared phenomenon that represents the frame as a whole.

Apart from being one of the most popular theories in media and communication research (Bryant \& Miron, 2004), framing theory has also been influential in research on climate change and the environment (e.g. Lakoff, 2010; Nisbet, 2009). Drawing on framing theory and the review of past research, this study is the first to examine (1) how sustainability is represented in constructive news and (2) by whom. While previous research has explored frames and sources without showing within which frame sources appeared (for an exception see Lewis, 2000), this study systematically integrates quoted sources into the analysis of frames to uncover associations between the two.

\section{Materials and methods}

\section{Sample}

This paper analyzed sustainability-related articles published in Positive News. Established in 1993 and printed in a newspaper format, Positive News relaunched in 2016 in a magazine format with an online version following a successful crowdfunding campaign (Roseingrave, 2015). It publishes a mix of factual and opinion content: journalist-authored articles; sponsored 
articles written by journalists under a "Brands of Inspiration" program which gives organizations the opportunity "to create a positive media footprint" in exchange for financial support (Positive News, 2017, 2018); "editor's letters" authored by editorial staff; and items labelled as "perspectives" or "opinion" written by external contributors. Positive News was the first publication dedicated to constructive journalism and it has an "Environment" section with a sub-section on "Sustainable Development". These factors make it an interesting exploratory case study of constructive reporting on sustainability.

The website of Positive News was searched using Google's Advanced Search function "site or domain" and the keywords "sustainability" or "sustainable" (borrowed from previous research) (see Bonfadelli, 2009 Diprose et al., 2017; Yacoumis, 2017). The timeframe was January 1, 2016 to December 31, 2017 (from the year of launching online to the closest full year at the time of commencing the analysis). The focus on the online version was motivated by its wider reach compared to the printed version (4,300 subscribers vs 460,000 unique visitors as of March 31, 2017) and the fact that Positive News publishes more items online than in print (Positive News, 2017). To be included in the final sample, an item had to focus on sustainability (items which mentioned the term, but dealt with a different topic were excluded) and be a journalist-authored article, which is not sponsored ("Brands of Inspiration" articles, editor's letters and perspectives/opinions were excluded). Of the total of 68 items that were returned ( 22 from 2016, 46 from 2017), 54 met the inclusion criteria and constitute the final sample (11 from 2016, 43 from 2017).

\section{Method}

The various methods of frame analysis that have been developed over the years can be grouped into deductive and inductive (Matthes \& Kohring, 2008). Deductive studies compile a list of frames from past research on the same or similar topic and scrutinize data for their presence. This approach has the strength of indicating frames' frequency of use, but holds the danger that content-specific frames may be missed by relying on a predefined list (Matthes \& Kohring, 2008). The inductive approach identifies frames with an open view, lowering the chance that frames could be overlooked. Its core strengths are the flexibility to register novel frames and the deep description of frames based on small samples (studies commonly analyze around 30 documents) (Matthes \& Kohring, 2008). The description of frames in inductive, qualitative analyses can be used as a starting point for further quantitative research.

This study adopted an inductive approach to frame analysis for two main reasons - the size of the sample, and the expectation that by representing a new type of journalism Positive News might feature frames that have not been previously identified (and could be omitted had a deductive approach been adopted). It applied a systematic approach for inductive frame analysis - a procedure developed by van Gorp (2010) and demonstrated in van Gorp \& van der Goot's (2012) exploratory, qualitative description of frames of sustainable food and agriculture in farming and food industry public communication materials. All 54 articles from the final sample were read multiple times and open-coded by the author. Excerpts fulfilling any of the four functions of a frame described by Entman (1993) were lifted and entered into a table which was completed for every article. Each functional feature was represented by a row and an additional row collated the sources which were quoted in the article to elaborate specific functional features of a frame (that is, their quote suggested a problem definition, cause, moral evaluation, and/or solution). Tables were constantly compared to identify similarities in propositions about problem definition, causes, moral evaluations and solutions. Articles making similar propositions were grouped together and re-read to identify an implicit cultural phenomenon that could be said to hold the functional features together. The final product of this inductive frame analysis is a qualitative description of frames (see van Gorp \& van der Goot, 2012). 


\section{Results}

The analysis identified three culturally-embedded frames: belief in the power of the market, belief in the power of science, and the value of camaraderie (see Table 1 for an overview). In each frame, an element of Western culture (a belief or a value) functioned as the central theme. In what follows, frames are described in alphabetical order using indicative, not exhaustive examples from the analyzed articles. All examples for the frame belief in the power of science are from 2017, reflecting evidence for this frame (which was confined to that year only).

Table 1 Frames

\begin{tabular}{|l|l|l|l|}
\hline & $\begin{array}{l}\text { Belief in the power of the } \\
\text { market }\end{array}$ & $\begin{array}{l}\text { Belief in the power } \\
\text { of science }\end{array}$ & $\begin{array}{l}\text { The value of } \\
\text { camaraderie }\end{array}$ \\
\hline $\begin{array}{l}\text { Problem } \\
\text { definition }\end{array}$ & $\begin{array}{l}\text { Mainstream businesses } \\
\text { which are wasteful and } \\
\text { engage in unethical } \\
\text { sourcing practices and } \\
\text { worker exploitation }\end{array}$ & $\begin{array}{l}\text { There are various } \\
\text { sustainability-related } \\
\text { challenges }\end{array}$ & $\begin{array}{l}\text { People are obsessed } \\
\text { with buying new }\end{array}$ \\
\hline Causes & None identified ${ }^{\text {vi }}$ & None identified & None identified \\
\hline Solutions & $\begin{array}{l}\text { - The market for } \\
\text { sustainable products } \\
\text { - Consumer demand for } \\
\text { sustainable products }\end{array}$ & $\begin{array}{l}\text { - Science and } \\
\text { technology hold the } \\
\text { key to solving the } \\
\text { various sustainability } \\
\text { challenges }\end{array}$ & $\begin{array}{l}\text { - Sharing and fixing } \\
\text { things together with } \\
\text { other people }\end{array}$ \\
\hline $\begin{array}{l}\text { Moral } \\
\text { evaluations }\end{array}$ & $\begin{array}{l}\text { - Mainstream businesses } \\
\text { are wasteful and unethical } \\
\text { - Sustainable businesses } \\
\text { are the exact opposite }\end{array}$ & None identified & None identified \\
\hline $\begin{array}{l}\text { Quoted } \\
\text { sources }\end{array}$ & $\begin{array}{l}\text { - Academia } \\
\text { - Ethical banks } \\
\text { - Government } \\
\text { - Social enterprises } \\
\text { - Sustainable businesses }\end{array}$ & - Citizens & $\begin{array}{l}\text { - Creative collectives } \\
\text { - Social enterprises } \\
\text { - Sustainability } \\
\text { charities }\end{array}$ \\
\hline
\end{tabular}

\section{Belief in the power of the market}

Mainstream businesses which do not espouse sustainability were portrayed as the problem and companies making sustainability efforts together with consumer demand for their products and services as the solution. Through evaluative lexis, articles in this frame communicated a moral evaluation of mainstream businesses. High street banks were described as "bad" (Scott, 2017) and fast fashion as "wasteful" (Cahalane, 2017). In contrast, ethical banks which fund sustainable projects were referred to as "positive" (Scott, 2017) and sustainable fashion businesses were referenced as producing clothes from "good stock" (Cahalane, 2017). Articles underlined businesses' ability to self-organize in bringing sustainability without the involvement of governments as in "offshore wind farm giant commits to building two huge schemes - without subsidies" (Farrington, 2017a) or even despite political decisions as in businesses "have vowed to press ahead with the Paris climate deal after President Trump announce[d] the US's withdrawal" (Purdy, 2017a). Commenting on this decision, an academic confirmed that businesses are "miles ahead in their assessment and responses to the threats posed by climate change" and a government official added that Trump "can't cancel the momentum that is behind [the Paris climate deal] economically" (Purdy, 2017a). 
Sustainable products, in this case, fashion items were presented as simultaneously better for the environment - having been made "using wind power"; for workers - as their social impact appears on labels reducing the likelihood of hidden workers' mistreatment; and for consumers - because "exploitation wears thin" faster (Cahalane, 2017). The contention was that by buying sustainable fashion items, people can "help fashion become a force for good" while "getting better quality pieces for [their] money" (Poore, 2017). Readers were encouraged to become "fashion revolutionaries", which "doesn't mean you have to stop buying and wearing the things you love", but rather "invest a little bit more in something that you think you'll wear for a long time" (Poore, 2017). This message that people's spending choices are key to sustainability was reflected in the words of an ethical bank representative quoted saying that "[w]here we spend, save and invest has a huge impact on our environment" (Lawson, 2017a). Articles provided information about various other sustainable products and services from "fairly produced" phones (Cahalane, 2016), plastic-free shops (Purdy, 2017b) and "green travel" (Millar, 2016) to a "wearable glitter alternative without the microplastics" allowing "glitter lovers" to "sparkle with a conscience" (Purdy, 2017c). In such articles, representatives of social enterprises and of sustainable businesses were quoted commenting that "from a sustainability perspective, [fairly produced phones] will make a big difference" (Cahalane, 2016) or that plastic-free shops are helping people buy "without creating any waste" (Purdy, 2017b). This frame (as the above examples demonstrate) was associated with the widest range of source types (compared to the other two frames, see also Table 1).

\section{Belief in the power of science}

An article describing a sustainable water treatment plant designed by engineering students which had enabled rural residents to drink clean water opened with the question "What's at stake in a world where science is marginalised?" (Koplinka-Loehr, 2017). Articles within this frame brought science and technology to the spotlight by presenting projects aimed to solve various sustainability challenges - "[s]cientists and inventors working on ways to clean up the plastic that is already in the sea" (Farrington, 2017b), a blockchain technology platform "lead[ing] a revolution in retail transparency" by allowing people to check "how ethically and sustainably" products had been sourced (Ross, 2017), more independence for remote village women previously "confined to their communities by conservative cultural norms" and now "leapfrogging into the digital age thanks to clean energy" (Wright, 2017). The latter article explained how Internet access enabled by clean energy is allowing these women to start up new businesses on their own (Wright, 2017). Elsewhere the focus was on the combined environmental and economic viability of new technologies such as community microgrids which allow people to "sell excess solar power they produced with rooftop panels", and a benefiting citizen was quoted saying "[i]t just makes sense from an environmental picture, and from a financial picture" (Lawson, 2017b). In addition to citizens, this frame was only reflected in the voices of entrepreneurs (and consequently, it was associated with the narrowest range of source types, see also Table 1). The creator of the blockchain platform referenced above spoke about using technology to "showcase the businesses that are really trying to be ethical" and helping people make informed consumer choices (Ross, 2017).

\section{The value of camaraderie}

In this frame, it was people's preoccupation with buying new that was identified as problematic. Articles spoke of "a society obsessed with acquisition" (Purdy, 2016), which needs to "ditch the disposable economy" and develop "a new relationship with "stuff" by sharing things with others and fixing things together, as "sharing and making are more positive ways to satisfy the innate human need for novelty" (Farrington, 2017c). A creative collective's representative charted her vision for the economy of the future as that "of maintenance, 
qualitative improvements, sharing, frugality and adaptation to natural limits" (Purdy, 2016). To solve the problem of "feverish pursuit of things (...) wreak[ing] ecological damage" (Purdy, 2016), articles suggested new "repair cafes" (Farrington, 2017c), "community repair groups" where "makers, tinkerers and anyone interested in making 'stuff' more sustainable" can gather (Lawson, 2017c), and "borrowing shop[s]" where people can hire anything from power tools to kitchenware instead of buying new (Farrington, 2016). A social enterprise representative was quoted saying "[f]ixing requires skill, teamwork (...) It is also a hands-on way to learn how our throwaway economy fails people and the planet" (Lawson, 2017c). One article explicitly referred to a "sense of comradery" thriving at such venues (Farrington, 2017c), while another asked "Could experiences, connection, community and a refreshed relationship with things better satisfy our needs?" (Purdy, 2016). Echoing this theme of comradery and togetherness, a representative of a sustainability charity emphasized how they "appeal to [people's] desire to meet other people, learn and have fun together" (Purdy, 2016) and "[u]nlike marketers, [we] don't treat others - or ourselves - as lonely individuals ruled by twitches".

\section{Discussion}

This exploratory study analyzed for the first time how sustainability is framed in a constructive media outlet (the UK's Positive News) and by whom. Approaching frames as culturallyembedded and using a qualitative, systematic inductive frame analysis procedure, it integrated the study of frames and quoted sources to identify three frames - belief in the power of the market (reflected in quotes from the widest range of source types), belief in the power of science (associated with the narrowest range of source types) and the value of camaraderie. While previous research has found that information on sustainability solutions is rarely offered in the news (Bonfadelli, 2009), all frames from the current study elaborated ways to achieve sustainability (see also Table 1). This would have largely been expected, as per constructive journalism's aim to offer a solution-oriented framing to important societal issues (McIntyre \& Gyldensted, 2018). Also contrary to previous findings that sustainability solutions tend to be reported "with a negative bias" (Bonfadelli, 2009, p. 275), articles from the present analysis consistently described working examples of possibility and progress regardless of whether solutions focused on market forces, scientific innovation or required rejecting the consumer culture. Sustainability is not a strictly scientific or environmental issue in the sense that it can be defined and achieved in purely objective and detached ways. It is also a social and political problem whereby solutions have to be discussed and legitimized in the public sphere in relation to culturally-shared values, beliefs and norms (Bonfadelli, 2009; Jaspal \& Nerlich, 2014). In this light, the presence of such hopeful, culturally-resonant visions of sustainability are a positive development from previous findings. Another point of deviation from existing research was that articles, overall, gave voice to a wider, and different range of sources than what is encountered in mainstream news reporting. In this sense, constructive coverage diverged from the "authority-orientation" of the news referring to reliance on sources from government and mainstream business (Hansen, 1991).

A final point of difference, which is especially significant in the light of existing critiques of the predominant (in the mainstream media) frames of market- and techno-scientific fixes was that constructive reporting offered an alternative frame of sustainability, not observed in previous research on mainstream news. The frame the value of camaraderie challenged consumerism and suggested that by connecting to something bigger - a wider community people can begin to notice their obsession with stuff and buying new. They can then start doing things differently - fixing and sharing things with others instead of valuing ourselves and others by how much we have or consume. Articles within this frame resonated with what Prádanos (2018, p. 2) has called "postgrowth cultural imaginaries" or stories that allow us to envision a desirable society not dependent on consumption and economic growth, but one that finds 
fulfillment while operating within the ecological limits of the planet. If consumerism relies on the value of "unrestricted individualism" (Castells, Caraça, \& Cardoso, 2012), it is perhaps unsurprising that this opposing, alternative frame was built around the value of camaraderie or togetherness at its core.

At the same time, constructive articles appeared to replicate previously-described sustainability frames focusing on technocratic, consumer-driven, market-focused solutions. Many of the critiques that have been voiced of how such frames have been elaborated in mainstream news reporting may consequently be raised in the context of the present study.

First, it can be argued that the frames belief in the power of the market and belief in the power of science reflected the storyline of the "green growth"/"ecological modernization" paradigm. These frames emphasized that the problem is mainstream business and consumer demand for its products and services, and the solution is embracing green products and services from sustainable businesses. The proposed solution thus takes a different path of consumption, but remains embedded in a paradigm focused on economic growth and consumer demand (Bäckstrand \& Lövbrand, 2006; Prádanos, 2018).

Second, articles within the frame belief in the power of the market positioned businesses as fully capable of self-organizing and providing sustainability solutions without the involvement or even in spite of government actions. Thus, attention was diverted away from other possible solutions such as what governments and regulations can do to encourage businesses to deliver a sustainable future, stop, or drastically reduce unsustainable practices. Such optimistic representations of businesses are symptomatic of a wider trend in environmentalism and climate change to increasingly move away from policy solutions and towards lifestyle and market solutions and technological fixes (e.g. Hellsten, Porter, \& Nerlich, 2014; Koteyko, 2012). This tendency is consistent with the broader "lifestyle project of neoliberal societies" focused on improving the self "through reflexive modes of consumption as a form of political citizenship" (Doyle, 2016, p. 778). The fact that these frames are being reproduced across media outlets and timeframes (see Diprose et al., 2017; Lewis, 2000; Yacoumis, 2017) including, as the present study found, in a constructive media outlet might be suggestive of "a deeper cultural consensus on the meaning of sustainability" (Yacoumis, 2017, p. 10). Also notable is that the frame belief in the power of the market was associated with the broadest range of source types, adding support that its vision of sustainability may be the most widely accepted and resonant with the most diverse groups in society.

Finally, solutions that appealed to readers to "invest a little bit more in something" (Poore, 2017) and not "buy something just because it's cheap" (Poore, 2017) meant that socioeconomic groups who do not have the means to follow this advice were excluded from the discussion of solutions. This can be seen as symptomatic of a link between sustainability and social class whereby it is framed as an aspirational, middle- and upper-class ideology (see e.g. Koteyko, 2012). When articles encouraged readers to look beyond price, they targeted a specific socio-economic audience. Indeed, concerns over this last point can be debated. On the one hand, if "overconsumption by the rich" (Ehrlich \& Ehrlich, 2013, p. 1) is among the major drivers of environmental problems, it is justifiable that sustainability solutions might target this group. On the other hand, following the 1992 UN Conference on Environment and Development, there has been emphasis on the inclusion of marginalized groups (e.g. lower socio-economic groups) in finding solutions to sustainability problems (Bäckstrand \& Lövbrand, 2006).

\section{Conclusion}

The main aim of this paper was exploratory. It illustrated the framing of sustainability and the use of sources in sustainability reporting in a constructive journalism media outlet, hoping this will provide an incentive for further such investigations as constructive journalism keeps 
growing. The most obvious limitations of this study are the focus on a single constructive journalism media outlet, the relatively small sample size, and the purely qualitative nature of the study where frames were identified by a single coder. Future research can expand the analysis to other publications which have endorsed constructive journalism, and quantify the presence of frames and sources while conducting intercoder reliability tests. More research is also needed on the effects of constructive journalism reporting about sustainability on readers' behavioral intentions. Despite these limitations, this study makes an innovative contribution by showing how constructive journalism can help move society to a sustainable future by (1) being solutions-focused, (2) reporting on sustainability solutions in an optimistic way, (3) giving readers the opportunity to hear the voices of a wider range of sources, and (4) offering alternative, socially desirable, culturally-resonant stories to live by.

\section{References}

Anderson, A. (2017). Source influence on journalistic decisions and news coverage of climate change. In M. C. Nisbet, S. S. Ho, E. Markowitz, S. O’Neill, M. S. Schäfer, \& J. Thaker (Eds.), The Oxford encyclopedia of climate change communication. (pp. 134). Oxford: Oxford University Press.

Bäckstrand, K., \& Lövbrand, E. (2006). Planting trees to mitigate climate change: contested discourses of ecological modernization, green governmentality and civic environmentalism. Global Environmental Politics, 6(1), 50-75.

Basiago, A. D. (1995). Methods of defining “sustainability". Sustainable Development, 3(3), 109-119.

Bell, A. (1991). The language of news media. Oxford: Blackwell.

Bonfadelli, H. (2009). Environmental sustainability as challenge for media and journalism. In M. Gross \& H. Heinrichs (Eds.), Environmental sociology: European perspectives and interdisciplinary challenges. (pp. 257-278). London: Springer.

Boudana, S. (2011). A definition of journalistic objectivity as a performance. Media, Culture \& Society, 33(3), 385-398.

Boykoff, M. T. (2007). Flogging a dead norm? Media coverage of anthropogenic climate change in United States and United Kingdom, 2003-2006. Area, 39, 470-481.

Bryant, J., \& Miron, D. (2004). Theory and research in mass communication. Journal of Communication, 54(4), 662-704.

Cahalane, C. (2016, January 12). Making phones fixable and more fairly produced. Positive News. Retrieved from https://www.positive.news/science/technology/making-phonesfixable-and-more-fairly-produced/

Cahalane, C. (2017, January 16). Nice threads: five of our favourite sustainable fashion projects. Positive News. Retrieved from https://www.positive.news/2017/economics/good-business/24771/nice-threads-fivefavourite-sustainable-fashion-projects/

Caple, H., \& Bednarek, M. (2013). Delving into the discourse: Approaches to news values in journalism studies and beyond. Working Paper. Oxford: Reuters Institute for the Study of Journalism.

Castells, M., Caraça, J., \& Cardoso, G. (2012). Aftermath: The cultures of the economic crisis. Oxford: Oxford University Press.

Curry, A. L., \& Hammonds, K. H. (2014). The power of solutions journalism. Engaging News Network/Solutions Journalism Network. Retrieved from http://engagingnewsproject.org/enp_prod/wp-content/uploads/2014/06/ENP_SJNreport.pdf.

Diprose, K., Fern, R., Vanderbeck, R. M., Chen, L., Valentine, G., Liu, C., \& McQuaid, K. (2017). Corporations, consumerism and culpability: sustainability in the British press, 
Environmental Communication. Advance online publication. doi:10.1080/17524032.2017.1400455

Donohue, G. A., Tichenor, P. J., \& Olien, C. N. (1995). A guard dog perspective on the role of media. Journal of Communication, 45(2), 115-132.

Doyle, J. (2016). Celebrity vegans and the lifestyling of ethical consumption. Environmental Communication, 10, 777-790.

Ehrlich, P. R., \& Ehrlich, A. H. (2013). Can a collapse of global civilization be avoided? Proceedings of the Royal Society B, 280(20122845), 1-9.

Elkington, J. (1997). Cannibals with forks: The triple bottom line of 21 st century business. Oxford: Capstone.

Entman, R. M. (1993). Framing: toward clarification of a fractured paradigm. Journal of Communication, 43(4), 51-58.

Farrington, K. (2016, September 23). Lending library offers shopping alternative. Positive News. Retrieved from https://www.positive.news/economics/lending-libraryshopping-alternative/

Farrington, K. (2017a, April 21). As Britain reaches coal-free milestone: 5 green energy breakthroughs. Positive News. Retrieved from https://www.positive.news/2017/environment/26687/britain-reaches-coal-freemilestone-5-green-energy-breakthroughs/

Farrington, K. (2017b, July 7). 5 possible solutions to ocean plastics. Positive News. Retrieved from https://www.positive.news/2017/environment/28009/5-possiblesolutions-ocean-plastics/

Farrington, K. (2017c, May 2). Making sense: are we ready to ditch the disposable economy? Positive News. Retrieved from https://www.positive.news/2017/economics/26820/making-sense-are-we-ready-toditch-the-disposable-economy/

Galtung, J., \& Ruge, M. (1965). The structure of foreign news: The presentation of the Congo, Cuba and Cyprus crises in four Norwegian newspapers. Journal of International Peace Research, 1, 64-91.

Gamson, W. A., \& Modigliani, A. (1989). Media discourse and public opinion on nuclear power: A constructionist approach. American Journal of Sociology, 95, 1-37.

Green, G. (2018). The express guide to constructive journalism. Retrieved from: https://www.ncvo.org.uk/guide-to-constructive-journalism

Gyldensted, C. (2015). From mirrors to movers: Five elements of positive psychology in constructive journalism. Ibadan: GGroup Publishers.

Haagerup, U. (2017). Constructive news (2nd ed.). Aarhus: Aarhus University Press.

Hall, S., Critcher, C., Jefferson, T., Clarke, J., \& Roberts, B. (1978). Policing the crisis: Mugging, the state and law and order. London: Macmillan.

Hansen, A. (1991). The media and the social construction of the environment. Media, Culture and Society, 13, 443-458.

Hansen, A. (2010). Environment, media and communication. London: Routledge.

Harcup, T., \& O'Neill, D. (2017). What is news? News values revisited (again). Journalism Studies, 18(12), 1470-1488.

Hellsten, I., Porter, A. J., \& Nerlich, B. (2014). Imagining the future at the global and national scale: a comparative study of British and Dutch press coverage of Rio 1992 and Rio 2012. Environmental Communication, 8, 468-488.

Herman, E. S., \& Chomsky, N. (1988). Manufacturing consent: the political economy of the mass media. New York, NY: Pantheon Books. 
Jaspal, R., \& Nerlich, B. (2014). When climate science became climate politics: British media representations of climate change in 1988. Public Understanding of Science, 23(2), 122-141.

Kemp, R., \& van Lente, H. (2011). The dual challenge of sustainability transitions. Environmental Innovation and Societal Transitions, 1(1), 121-124.

Kensicki, L. J. (2004). No cure for what ails us: the media-constructed disconnect between societal problems and possible solutions. Journalism \& Mass Communication Quarterly, 81(1), 53-73.

Koplinka-Loehr, C. (2017, March 22). This invention lets rural Hondurans clean their water and own the treatment plants. Positive News. Retrieved from https://www.positive.news/science/invention-lets-rural-hondurans-clean-watertreatment-plants/

Koteyko, N. (2012). Managing carbon emissions: a discursive presentation of "market-driven sustainability" in the British media. Language \& Communication, 32, 24-35.

Lakoff, G. (1995). Metaphor, morality, and politics, or why Conservatives have left liberals in the dust. Social Research, 62(2), 177-214.

Lakoff, G. (2010). Why it matters how we frame the environment. Environmental Communication, 4(1), 70-81.

Lakoff, G., \& Johnson, M. (1980). Metaphors we live by. Chicago: University of Chicago Press.

Lawson, T. (2017a, December 8). Dreaming of an ethical Christmas? 2017 set to be the best year yet for 'conscious' seasonal spending. Positive News. Retrieved from https://www.positive.news/economics/dreaming-ethical-christmas-2017-set-best-yearyet-conscious-seasonal-spending/

Lawson, T. (2017b, July 21). NYC residents trade solar energy with their neighbours. Positive News. Retrieved from https://www.positive.news/2017/environment/28428/nyc-residents-trade-solarenergy-neighbours/

Lawson, T. (2017c, September 12) The joy of fix: a festival for repair-lovers will take place in London. Positive News. Retrieved from https://www.positive.news/2017/lifestyle/29339/joy-fix-festival-repair-lovers-willtake-place-london/

Lewis, T. (2000). Media representations of "sustainable development". Science Communication, 21, 244-273.

Lough, K., \& McIntyre, K. (2018). Journalists' perceptions of solutions journalism and its place in the field. \#ISOJ Journal, 8(1), 33-52.

Major, A., \& Atwood, E. L. (2004). Environmental stories define problems, not solutions. Newspaper Research Journal, 3, 8-22.

Matthes, J. (2009). What's in a frame? A content analysis of media-framing studies in the world's leading communication journals, 1990-2005. Journalism \& Mass Communication Quarterly, 86, 349-367.

Matthes, J., \& Kohring, M. (2008). The content analysis of media frames: toward improving reliability and validity. Journal of Communication, 58(2), 258-279.

McIntyre, K. (2017). Solutions journalism: the effects of including solution information in news stories about social problems. Journalism Practice, 90, 1-19.

McIntyre, K., \& Gyldensted, C. (2017). Constructive journalism: an introduction and practical guide for applying positive psychology techniques to news production. Journal of Media Innovations, 4(2), 20-34.

McIntyre, K., \& Gyldensted, C. (2018). Positive psychology as a theoretical foundation for constructive journalism. Journalism Practice, 12(6), 662-678. 
Millar, A. (2016, August 9). Positive destinations. Positive News. Retrieved from https://www.positive.news/lifestyle/travel/positive-destinations/

Nisbet, M. C. (2009). Communicating climate change: why frames matter for public engagement. Environment Magazine, 51(2), 14-23.

Poore, H. (2017, April 25). 5 ways to help fashion become a force for good. Positive News. Retrieved from https://www.positive.news/2017/lifestyle/arts/26726/5-ways-helpfashion-become-force-good/

Positive News. (2017). Positive News annual review 2016/17. Retrieved from https://www.positive.news/wpcontent/uploads/2017/09/positivenews_annualreview2016-17.pdf

Positive News. (2018). Brands of inspiration. Retrieved from https://www.positive.news/partners/

Prádanos, L. I. (2018). Postgrowth Imaginaries: New Ecologies and Counterhegemonic Culture in Post-2008 Spain - Introduction. Modern Languages Open. Retrieved from https://www.modernlanguagesopen.org/articles/abstract/245/\#

Prasad, P., \& Elmes, M. (2005). In the name of the practical: unearthing the hegemony of pragmatics in the discourse of environmental management. Journal of Management Studies, 42(4), 845-867.

Princen, T., Maniates, M., \& Conca, K. (2002). Confronting consumption. In T. Princen, M. Maniates \& K. Conca (Eds.), Confronting consumption. (pp. 1-20). Cambridge, MA: The Massachusetts Institute of Technology Press.

Purdy, L. (2016, June 10). True riches: rethinking our relationship with stuff. Positive News. Retrieved from https://www.positive.news/lifestyle/true-riches-rethinkingrelationship-stuff/

Purdy, L. (2017a, June 2). 'Trump can't cancel the momentum behind the Paris climate deal'. Positive News. Retrieved from https://www.positive.news/environment/trump-cantcancel-the-momentum-behind-the-paris-climate-deal/

Purdy, L. (2017b, October 17). London's first plastic-free shop opens. Positive News. Retrieved from https://www.positive.news/2017/environment/29867/londons-firstplastic-free-shop-opens/

Purdy, L. (2017c, October 24). Entrepreneur offers a wearable glitter alternative without the microplastics. Positive News. Retrieved from https://www.positive.news/2017/environment/29956/entrepreneur-offers-wearableglitter-without-the-microplastics/

Roseingrave, L. (2015, August 17) Positive News gives readers a say in the kind of journalism it produces. The Irish Times. Retrieved from https://www.irishtimes.com/business/positive-news-gives-readers-a-say-in-the-kindof-journalism-it-produces-1.2314902

Ross, E. (2017, July 11). Digital startup aims to lead a revolution in retail transparency.

Positive News. Retrieved from https://www.positive.news/economics/digital-startupaims-lead-revolution-retail-transparency/

Scheufele, D. A. (1999). Framing as a theory of media effects. Journal of Communication, 49(1), 103-122.

Scott, M. (2017, February 28). Could banks not just be less bad, but a force for positive change? Positive News. Retrieved from https://www.positive.news/economics/banksnot-just-less-bad-force-positive-change/

Tuchman, G. (1972). Objectivity as strategic ritual: an examination of newsmen's notions of objectivity. American Journal of Sociology, 77(4), 660-679.

UN. (2015). Transforming our world: the 2030 Agenda for Sustainable Development. Retrieved from https://sustainabledevelopment.un.org/post2015/transformingourworld 
van Gorp, B. (2007). The constructionist approach to framing: Bringing culture back in. Journal of Communication, 57, 60-78.

van Gorp, B. (2010). Strategies to take subjectivity out of framing analysis. In P. D'Angelo \& J. A. Kuypers (Eds.), Doing news framing analysis: empirical and theoretical perspectives. (pp. 84-109). New York,NY: Routledge.

van Gorp, B. \& van der Goot, M. J. (2012). Sustainable food and agriculture: stakeholder's frames. Communication, Culture \& Critique, 5, 127-148.

Wright, M. (2017, May 12). Solar sisters: how green energy is empowering women in remote communities. Positive News. Retrieved from https://www.positive.news/2017/environment/energy/26994/solar-sisters-greenenergy-empowering-women-remote-communities/

WCED. (1987). Our common future. Oxford: Oxford University Press.

Yacoumis, P. (2017). Making progress? Reproducing hegemony through discourses of "sustainable development" in the Australian news media. Environmental

Communication. Advance online publication. doi:10.1080/17524032.2017.1308405.

Ziemann, A. (2011). Communication theory and sustainability discourse. In J. Godemann \&

G. Michelsen (Eds.), Sustainability communication (pp. 89-96). Houten: Springer.

\footnotetext{
i Yacoumis (2017) labels these "discursive themes". As his description of these themes focuses on problem definitions and solution recommendations (two of the functional features of frames as per Entman's (1993) seminal definition), this paper refers to them as "frames".

ii Italics are used to mark frames.

${ }^{\text {iii }}$ For a comprehensive review of news values definitions see Caple \& Bednarek (2013).

iv This type of news has also been called "solutions journalism" (see McIntyre \& Gyldensted, 2017).

${ }^{v}$ Evidence on the link between solutions reporting and intentions to act is only beginning to emerge; some researchers find no connection (see McIntyre, 2017).
}

\footnotetext{
${ }^{\mathrm{vi}}$ A frame may not necessarily elaborate all four elements (problem definition, causes, solutions, moral evaluations) (see Entman, 1993), which is denoted with "None identified".
} 